\title{
PERBANDINGAN KECEPATAN KONVERGENSI AKAR PERSAMAAN NON LINIER METODE TITIK TETAP DENGAN METODE NEWTON RAPHSON MENGGUNAKAN MATLAB
}

\author{
Januari Ritonga, Dede Suryana \\ Program Studi Teknik Informatika dan Program Studi Sistem Infromasi \\ STMIK Indonesia Mandiri, Jl.Jakarta No.79 Bandung
}

\begin{abstract}
ABSTRAK
Metode Numerik adalah suatu teknik yang digunakan untuk memformulasikan persoalan matematika, sains dan rekayasa sedemikian sehingga dapat diselesaikan dengan cara operasi perhitungan aritmatika biasa. Tujuan penelitian ini adalah membandingkan kecepatan konvergensi penentuan akar persamaan atau fungsi non linier metode Titik Tetap dengan metode Newton Raphson menggunakan Matlab. Hasil perhitungan dengan program aplikasi Matlab menunjukkan bahwa, kecepatan konvergensi menuju akar dengan metode Newton Raphson lebih cepat dibanding metode Titik Tetap. Kecepatan rata-rata iterasi dengan tingkat kesalahan atau galat pada 0,00001 , sebesar $64 \%$ lebih cepat.
\end{abstract}

Kata kunci : Titik Tetap, Newton Raphson, Matlab.

\section{PENDAHULUAN}

Dalam beberapa persoalan matematika dan persoalan rekayasa atau persoalan tertentu lainnya tidaklah cukup kita hanya menggunakan metode untuk memperoleh hasil yang diinginkan, kita juga perlu mengetahui apakah metode tersebut memang memberikan solusi hampiran, dan seberapa bagus hampiran itu, hal ini melahirkan kajian baru, yaitu analisis numerik.

Metode numerik dan analisis numerik adalah dua hal yang berbeda. Metode adalah algoritma, menyangkut langkah-langkah penyelesaian persoalan secara numerik, sedangkan analisis numerik adalah terapan matematika untuk menganalisis metode. Dalam analisis numerik, hal utama yang ditekankan adalah analisis galat dan kecepatan konvergensi sebuah metode. Teorema-teorema matematika banyak dipakai dalam menganalisis suatu metode. Tugas para analis numerik ialah mengembangkan dan menganalisis metode numerik, termasuk di dalamnya pembuktian apakah suatu metode konvergen, dan menganalisis batas-batas galat solusi numerik.Terdapat banyak sumber galat, diantaranya tingkat ketelitian model matematika, sistem aritmetik komputer, dan 
kondisi yang digunakan untuk menghentikan proses pencarian solusi. Semua ini harus dipertimbangkan untuk menjamin ketelitian solusi akhir yang dihitung.

Dalam tulisan ini yang dibahas adalah penentuan akar-akar persamaan fungsi non linier. Permasalahan pada persamaan non linier adalah dalam penentuan akar-akar persamaan, dimana akar sebuah persamaan $\mathrm{f}(\mathrm{x})=0$, adalah nilai-nilai $\mathrm{x}$ yang mengakibatkan nilai $\mathrm{f}(\mathrm{x})$ sama dengan nol. Secara geometri akar-akar persamaan adalah titik potong antara kurva $\mathrm{f}(\mathrm{x})$ dengan sumbu-x pada sistem koordinat cartesius.

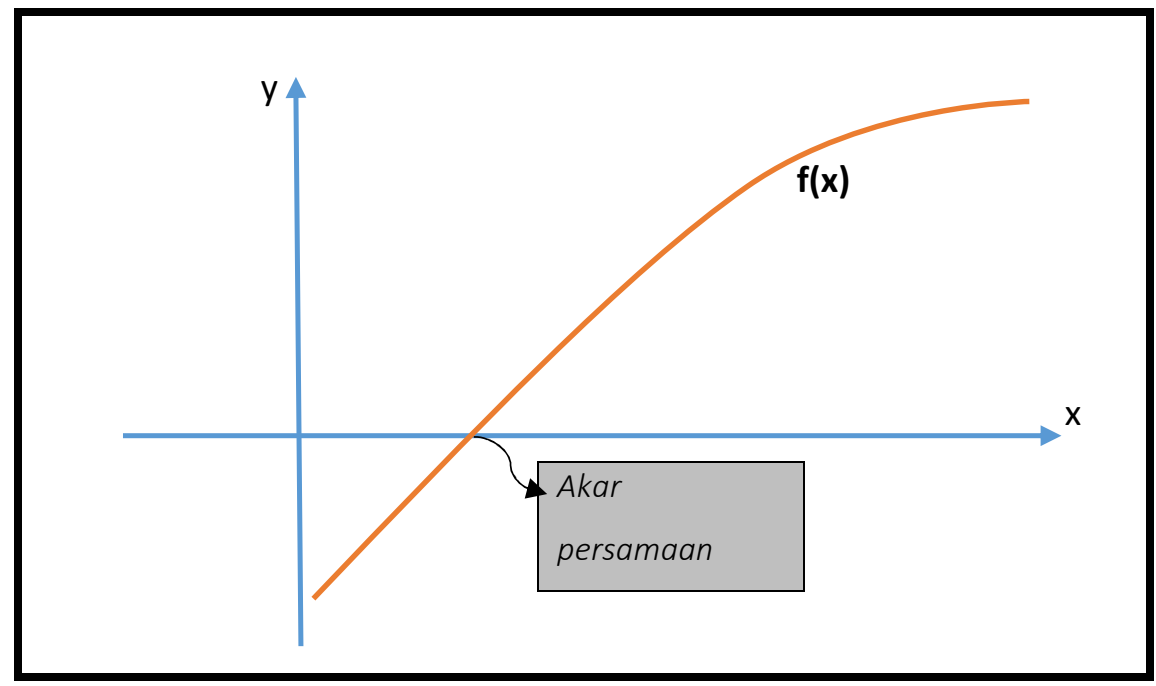

Gambar 1. Titik potong $\mathrm{f}(\mathrm{x})$ dengan sumbu- $\mathrm{x}$

Penentuan akar persamaan untuk fungsi-fungsi non linier yang sederhana dapat dengan mudah diselesaikan dengan metode analitis atau metode-metode eksak, misalnya untuk persamaan kuadrat $a x^{2}+b x+c=0$, dapat diselesaikan dengan menggunakan rumus abc atau dengan metode pemfaktoran. Untuk fungsi-fungsi yang tidak sederhana atau komplek misalnya fungsi-fungsi $x-e^{-x}=0$, atau $x e^{-x}+1=0$ ,sepintas tampaknya sederhana, tetapi ternyata untuk menyelesaikan persamaan non linier ini merupakan metode pencarian akar secara berulang ulang, sehingga hasil yang diperoleh akan mengandung galat dan proses perhitungannya panjang dan melelahkan apalgi jika dilakukan secara manual. Banyak cara metode untuk menetukan akarakar persamaan non linier secara numerik misalnya metode Bagidua (biseksi), metode Titik Palsu (Titik Tetap, metode Newton Raphson, dan metode Secant. Dalam tulisan ini penentuan akar persamaan non linier menggunakan metode Titik Tetap dan metode 
Newton Rapshon untuk dibandingkan kecepatan konvergensinya dengan menggunakan aplikasi MATLAB.

\section{LANDASAN TEORI}

\section{A. Metode Numerik dan Pemodelan Masalah Rekayasa}

Metode Numerik adalah suatu teknik yang digunakan untuk memformulasikan atau merumuskan masalah matematis, dana atau masalah rekayasa agar dapat dipecahkan dengan operasi perhitungan. Proses metode numerik melibatkan sejumlah besar perhitungan yang melelahkan dan menjemukan, sehingga peranan komputer akan sangat membantu.

Metode numerik merupakan alat pemecahan yang sangat ampuh, dalam menangani system persamaan yang besar, ketidaklinieran, dan masalah geometri yang rumit. Pada saat ini setelah tumbuh pesatnya perangkat lunak dan perangkat keras computer pemecahan masalah rakayasa dapat dibantu dengan program computer, namun ada juga persoalan yang tidak bisa didekati dengan memakai program paket. Jika ini terjadi maka kita harus merancang dan membuat program sendiri. Metode numerik adalah sarana yang efisien untuk mempelajari penulisan program dengan baik dan benar. Metode numerik menyediakan suatu sarana untuk memperkuat pengertian matematika dan berguna dalam penyederhanaan matematika yang lebih tinggi/rumit menjadi operasi-operasi matematikan yang sederhana dan mendasar.

Dalam suatu proses penelitian dan pengkajian, hasil penelitian tersebut didapat melalui pengamatan yang berulang-ulang. Perilaku demikian kemudian dapat diekspresikan sebagai hokum dasar yang secara esensial mewujudkan kearifan kumulatif dan pengalaman, sehingga kebanyakan pemecahan masalah rekayasa merupakan kedua cabang pendekatan yaitu empiris dan analitis teoritis.

Bagan dibawah ini menunjukan proses pemecahan masalah rekayasa. 


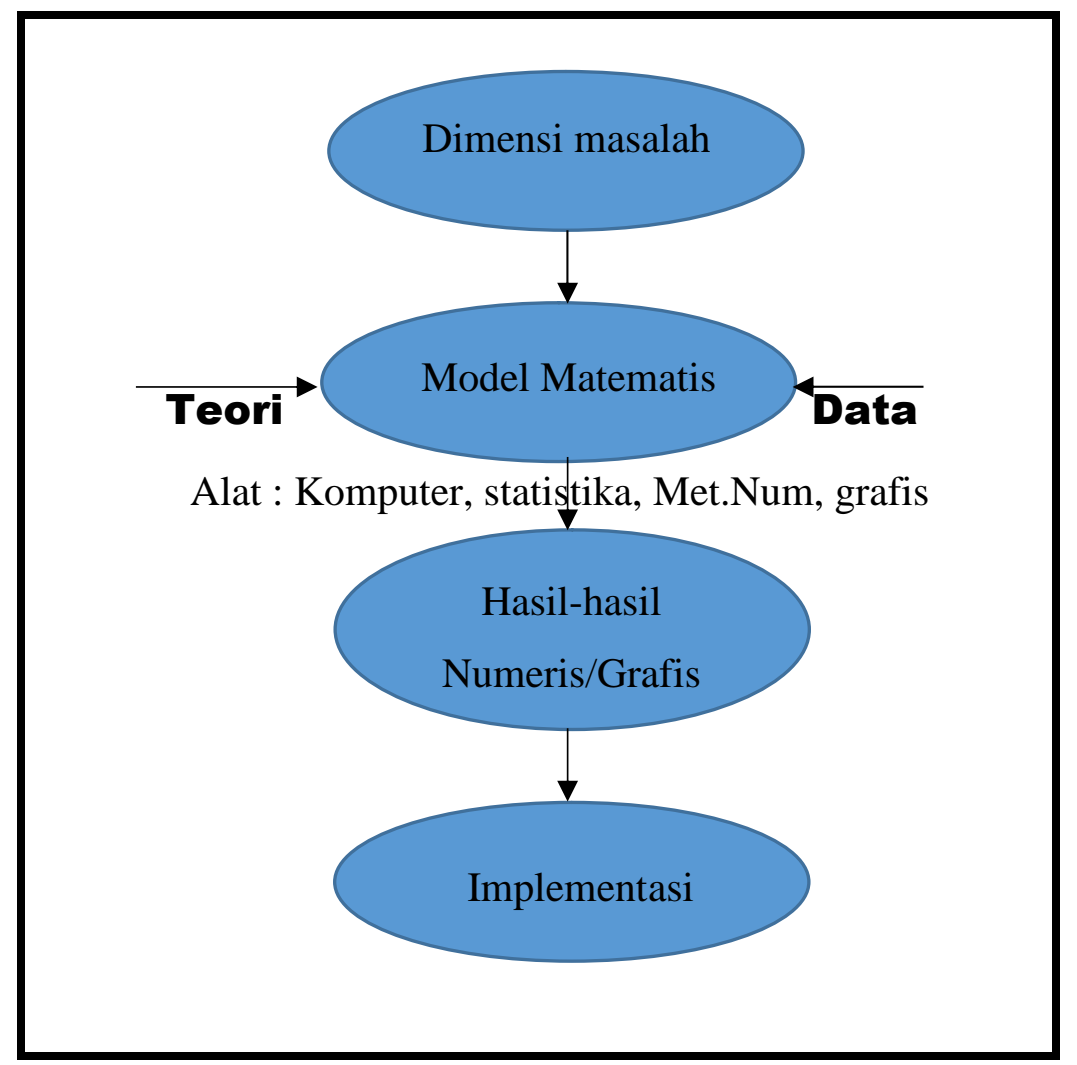

Gambar 2. Proses Pemecahan Masalah Rekayasa

Dalam proses pemecahan masalah dari data-data yang diperoleh, bagaimana cara yang baik untuk mempresentasikan data tersebut kedalam bentuk yang lebih mudah dibaca dan mudah dipahami, untuk ini para pakar mebuat model, khususnya model matematis yang dinyatakan dalam bentuk fungsi matematis. Model matematis dapat didefinisikan sebagai perumusan atau persamaan yang mengekpresikan feature pokok dari system atau proses fisik. Model matematis umumnya dapat dinyatakan sebagai suatu hubungan fungsional yang berbentu :

\section{Variabel Terikat $=\mathbf{f}($ var. bebas, parameter, fungsi kendala $)$}

Atau dalam simbol-simbol matematis dinyatakan :

$$
y=f\left(x_{1}, x_{2}, \ldots, x_{n}\right)
$$


Persamaan mempunyai sejumlah ciri khas dari model matematika, yaitu :

1. Persamaan tersebut menggambarkan suatu proses dari system biasa dalam istilah matematika

2. Persamaan tersebut menyatakan suatu idealism/penyederhanaan dari keadaan yang sebenarnya.

3. Persamaan tersebut memberikan hasil yang dapat direproduksi dan oleh karena itu dapat dipakai untuk tujuan peramalan.

Karena diproses secara berulang-ulang, maka perlu diperhatikan masalah-masalah berapa kalikah pengulangan harus dilakukan ?, dalam toleransi berapa persenkan hasil pengamatan/pengkajian/pengukuran dapat dikatakan vali atau tidak ?, dan metodemetode atau rumus-rumus apa saja yang dipakai untuk memproses data yang didapat.

Dalam tulisan penelitian ini dilakukan penentuan akar persamaan non linier metode Titik Tetap dan metode Newton Raphson dengan aplilkasi MathLab.

\section{B. Akar Persamaan Non Linier Metode Titik Tetap}

Teknik menentukan hampiran akar persamaan secara umum tergantung pada dugaan nilai awal yang mengapit nilai akar. Dalam beberapa kasusu hal ini sulit dilakukan, sehingga diperlukan suatu metode yang tidak memerlukan informasi awal. Salah satu metode yang demikian adalah Metode Titik Tetap. Misalkan diberikan $\mathbf{f}(\mathbf{x})=$ 0 yang dapat dituliskan dalan bentuk baru $\mathbf{x}=\mathbf{g}(\mathbf{x})$ dimana setiap penyelesaian persamaan ini disebut titik tetap g. Dengan memilih nilai awal sembarang xo, maka dapat dilakukan pengulangan/iterasi perhitungan hampiran titik-titik tetap fungsi g, sebagai berikut :

$$
x_{n+1}=g\left(x_{n}\right) \quad x=0,1,2,3, \ldots .
$$

Dengan melakukan iterasi ini diharapkan diperoleh deret $x_{0} x_{1}, x_{2}, x_{3}, \ldots \quad$ Yang konvergen menuju akar.

Algoritma Metode Titik Tetap untuk menentukan akar persamaan adalah sebagai berikut : 


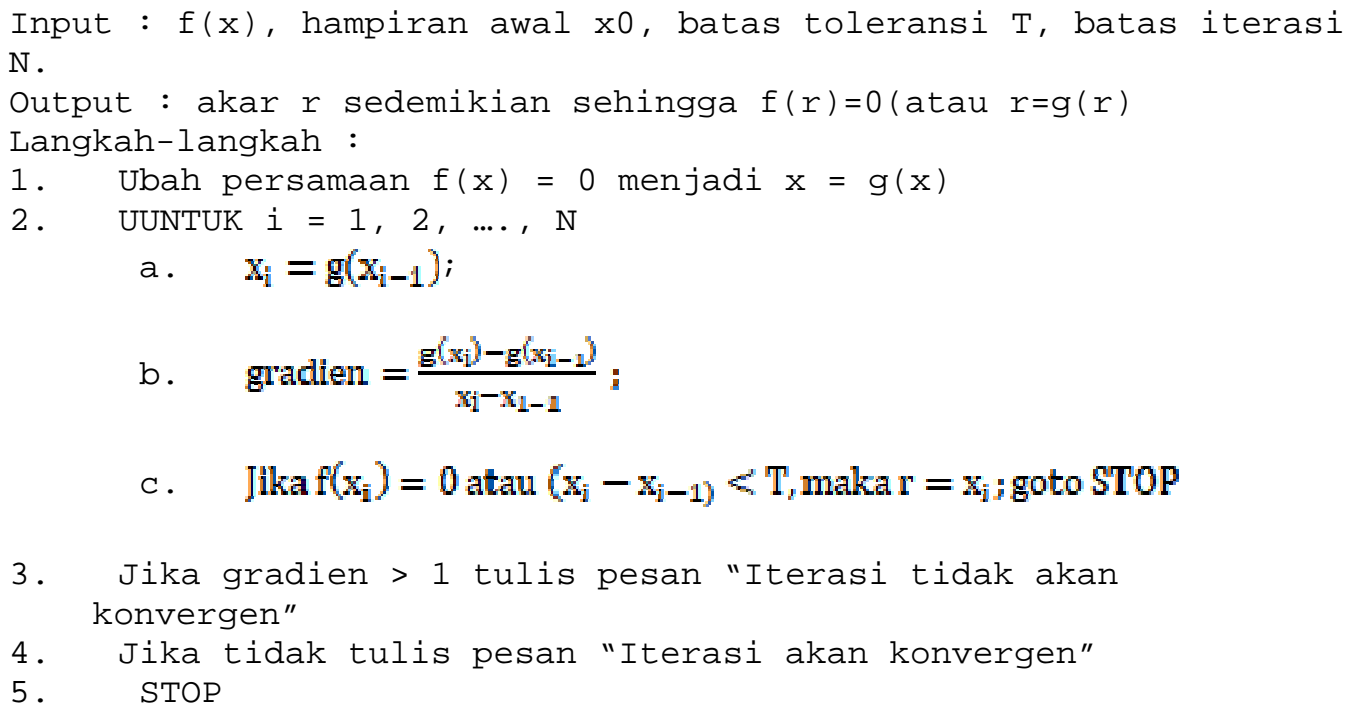

Berikut adalah program perhitungan akar persamaan non linier metode Titik Tetap untuk berbagai fungsi dengan program Matlab.

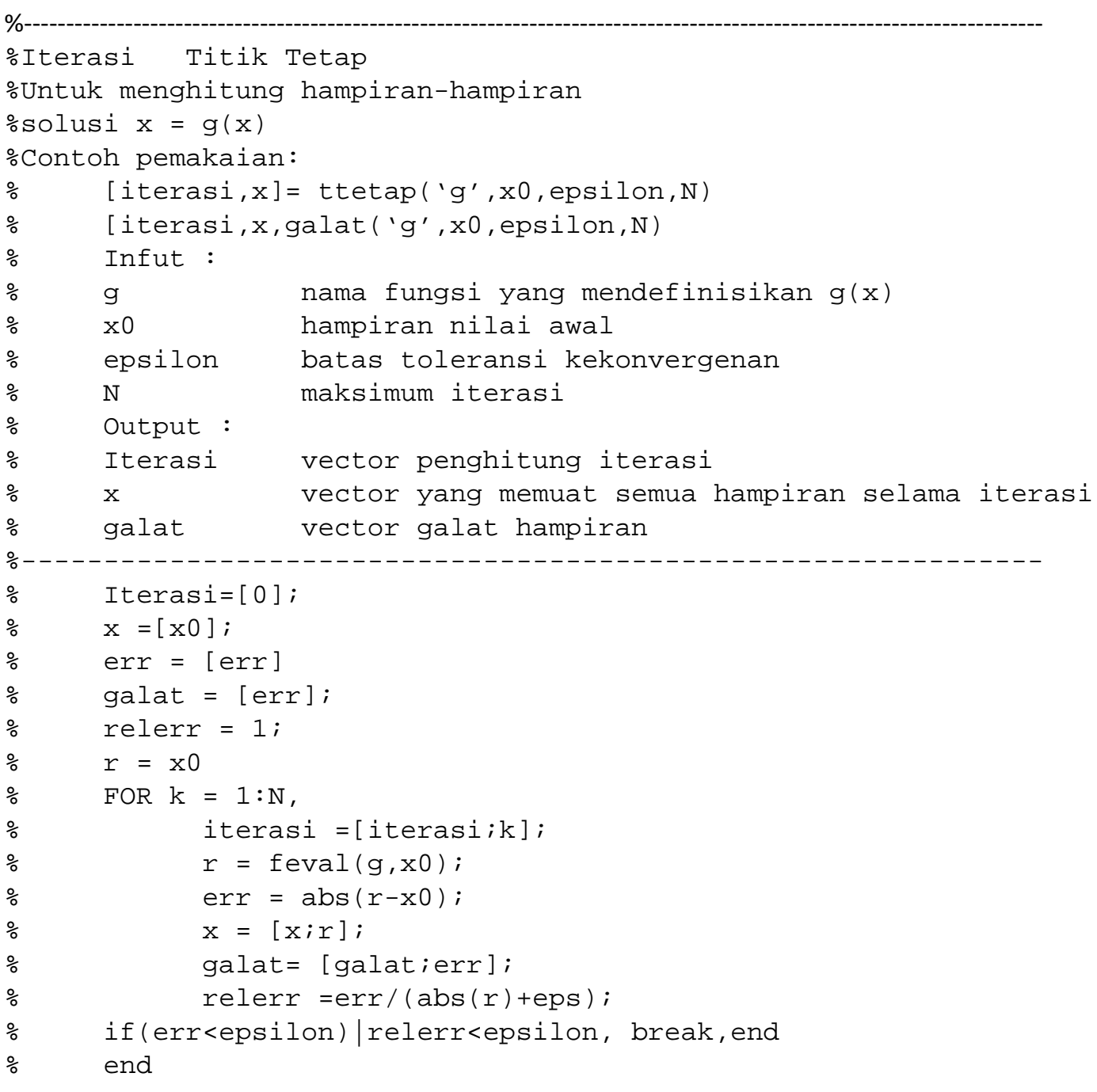




\section{Akar Persamaan Non Linier Metode Newtoh Raphson}

Selain metode titik tetap dalam pencarian akar persamaan non linier, ada juga yang diseut metode Newton Raphson. Dalam beberapa referensi menyebutkan metode Newton saja. Joseph Raphson (1648-1715) adalah matematikawan Inggris yangmempublikasikan metode Newton.

Perumusan iterasi Metode Newton dapat dilakukan dengan pendekatan geometris, atau dengan pendekatan deret Taylor.

1. Pendekatan iterasi secara geometri

Penentuan rumus iterasi dengan pendekatan geometri adalah sebagai berikut, perhatikan gambar dibawah ini

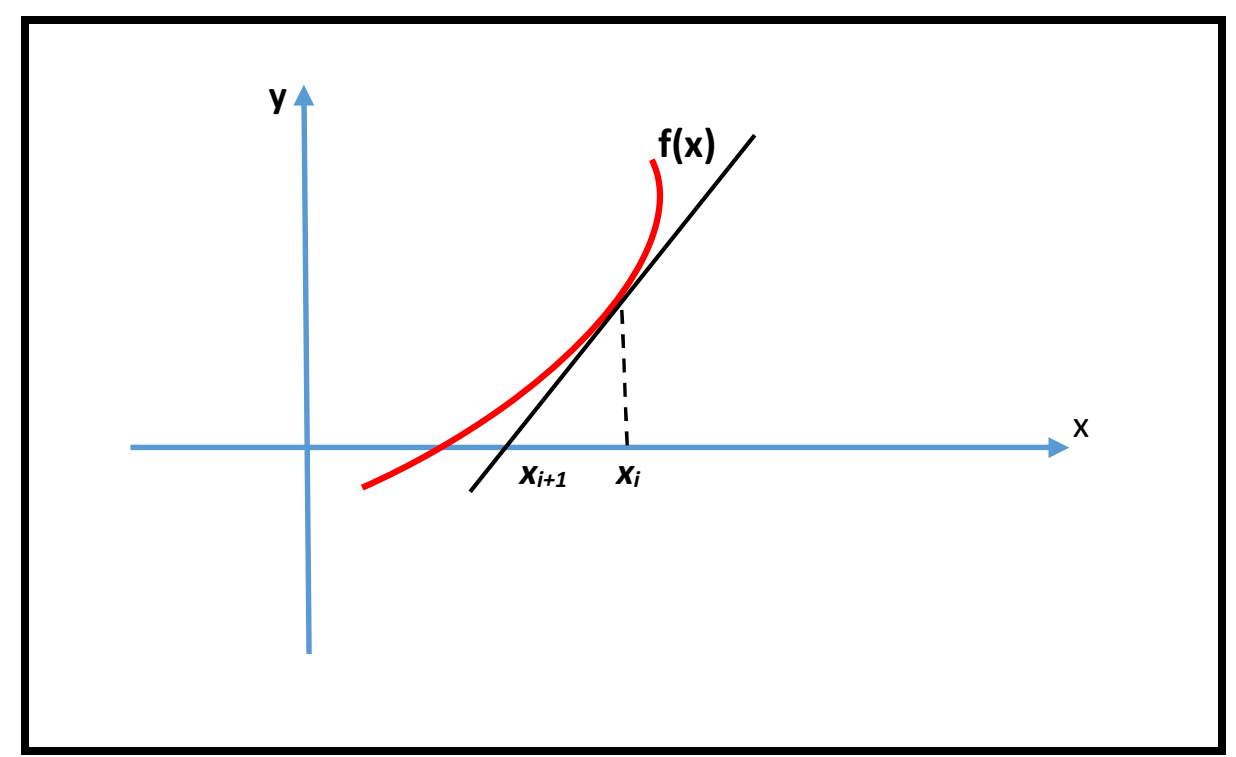

Gambar 3. Analisis Geometri Metode Newton Raphson

Dari gambar di atas kemiringan/gradien garis singgung di sekitar akar adalah $\mathrm{x}_{\mathrm{r}}$ :

$$
m=f^{\prime}\left(x_{r}\right)=\frac{\Delta y}{\Delta x}=\frac{f\left(x_{r}\right)-0}{x_{r}-x_{r+1}}
$$

atau

$$
f^{\prime}\left(x_{r}\right)=\frac{f\left(x_{r}\right)}{x_{r}-x_{r+1}}
$$

sehingga prosedur iterasi Metode Newton Raphson dengan pengekplisitkan $\boldsymbol{x}_{\boldsymbol{r}+\boldsymbol{1}}$ adalah: 


$$
x_{r+1}=x_{r}-\frac{f^{(}\left(x_{r}\right)-0}{f^{\prime}\left(x_{r}\right)} \quad, \text { dengan } \mathrm{f}^{\prime}(\mathrm{x}) \neq 0
$$

2. Pendekatan iterasi dengan bantuan deret Taylor

Deret Taylor didefinisikan sebagai suatu fungsi f dan semua turunannya pada interval tertutup [a, b], da nada

$$
f(x)=f\left(x_{o}\right)+\frac{\left(x-x_{o}\right)}{1 !} f^{\prime}\left(x_{0}\right)+\frac{\left(x-x_{o}\right)^{2}}{2 !} f^{\prime \prime}\left(x_{o}\right)+\ldots .+\frac{\left(x-x_{o}\right)^{m}}{m !} f^{(m)}\left(x_{o}\right)+\ldots
$$

Apabila deret ini dipotong sampai dengan orde ke-2, maka deret Tayloy

$$
\text { menjadi } f(x)=f\left(x_{o}\right)+\frac{\left(x-x_{o}\right)}{1 !} f^{\prime}\left(x_{0}\right) \text {, }
$$

dengan $1 !=1$, sehingga untuk uraian $f\left(x_{r+1}\right)$ didapat,

$$
f\left(x_{r+1}\right)=f\left(x_{r}\right)+\left(x_{r+1}-x_{r}\right) f^{\prime}\left(x_{r}\right)
$$

Akar persamaan diperoleh jika $f\left(x_{r+1}\right)=0$, dengan demikian prosedur iterasi yang merupakan itersi Newton Raphson adalah :

$$
x_{r+1}=x_{r}-\frac{f\left(x_{r}\right)}{f^{\prime}\left(x_{r}\right)}
$$

Iterasi Newton Raphson berhenti apabila, $\left|x_{r+1}-x_{r}\right|<\varepsilon$, atau secara relative

$$
\left|\frac{x_{r+1}-x_{r}}{x_{r+1}}\right|<\delta
$$

Berikut adalah implementasi program metode Newton Raphson, untuk perhitungan dengan berbagai fungsi. 


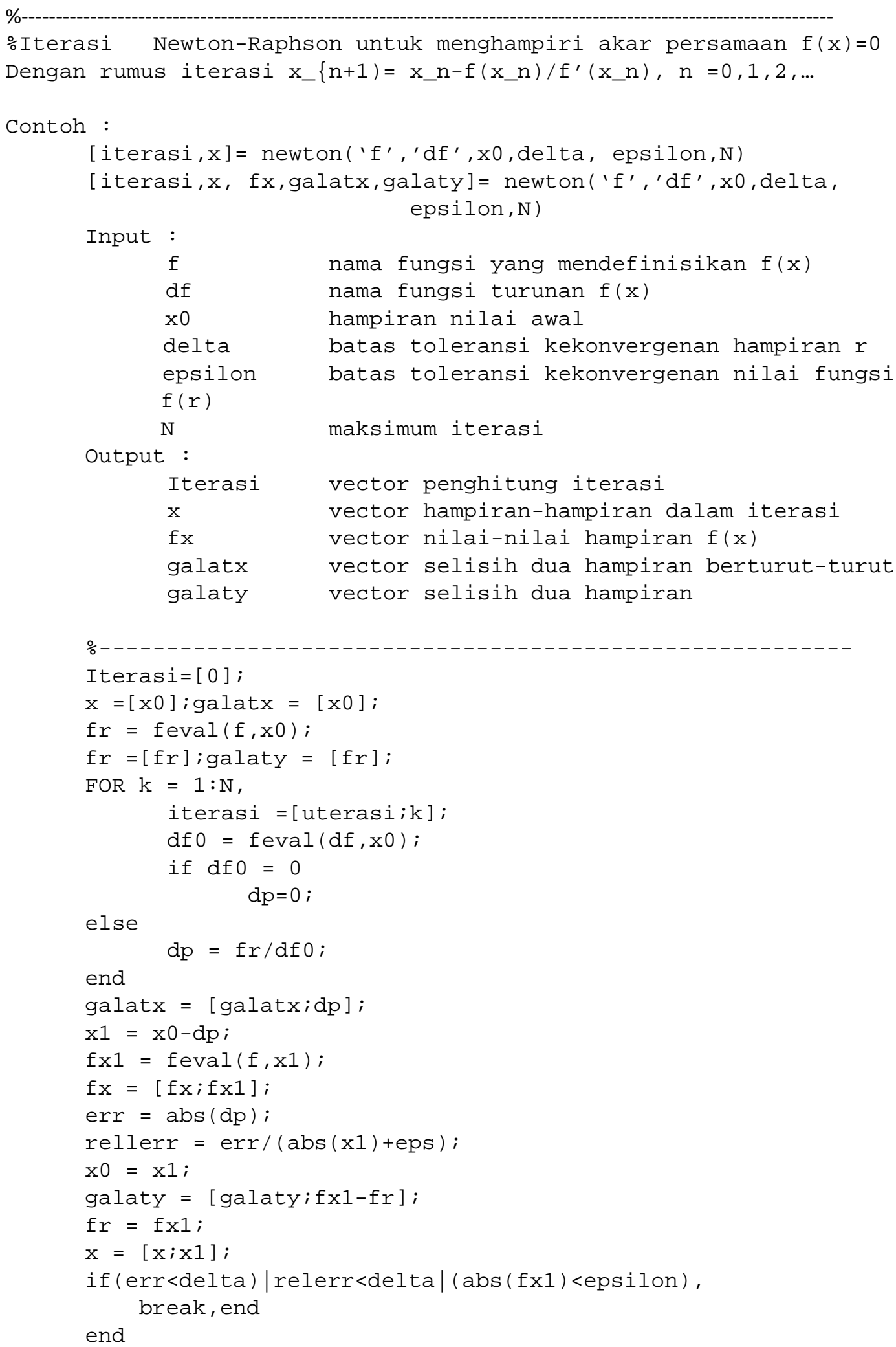


Fungsi yang akan digunakan secara umum harus dibuat dalam dua buah file, yaitu file untuk fungsi $y=f(x)$, dan file untuk fungsi turunannya $y=d f(x)$

Misal untuk file fungsi $\mathrm{y}=\mathrm{f}(\mathrm{x})$ :

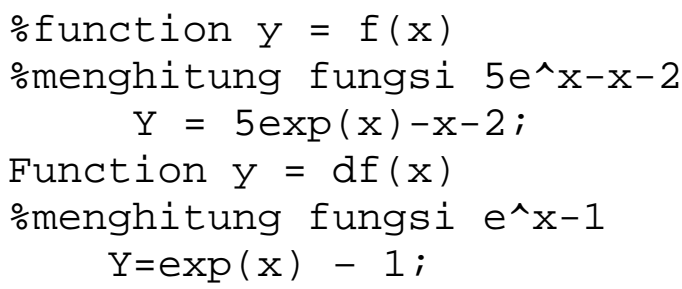

\section{Kriteria Kekonvergenan}

Misalkan $\boldsymbol{x}_{\boldsymbol{0}}, \boldsymbol{x}_{\boldsymbol{1}}, \boldsymbol{x}_{2}, \ldots, \boldsymbol{x}_{\boldsymbol{n}}, \boldsymbol{x}_{\boldsymbol{n}+\boldsymbol{1}}$, adalah nilai-nilai akar hampiran yang diperoleh melalu iterasi berturut-turut dalam Metode Newton Raphson.

Jika r adalah akar sejati dan $\boldsymbol{\varepsilon}$ adalah galatpada iterasi ke-n, naka $\boldsymbol{\varepsilon}=\boldsymbol{x}_{\boldsymbol{n}}-\boldsymbol{r}$, dan

$$
\begin{gathered}
\varepsilon_{n+1}=x_{n+1}-r=x_{n}-\frac{f\left(x_{n)}\right.}{f^{\prime}\left(x_{m}\right)}-r \\
=x_{n}-r-\frac{f\left(x_{n}\right)}{f^{\prime}\left(x_{n}\right)}=\varepsilon_{n}-\frac{f\left(x_{n}\right)}{f^{\prime}\left(x_{n}\right)} \\
=\frac{\left(\varepsilon_{n} f^{\prime}\left(x_{n}\right)-f\left(x_{n}\right)\right.}{f^{\prime}\left(x_{n}\right)}
\end{gathered}
$$

Jika bentuk diatas diekspansi dalam bentuk deret Taylor, didapat suatu kriteria konvergen dari metode Newton Raphson yaitu,

$$
\varepsilon_{n+1}=\frac{f^{\prime \prime}\left(c_{n}\right) \varepsilon_{n}^{2}}{2 f^{\prime}\left(x_{n}\right)}
$$

Sementara itu kriteria konvergensi untuk metode Titik Tetap dapat dijelaskan sebagai berikut :

Dari prosedur iterasi titik tetap $\quad x_{r+1}=g\left(x_{r}\right)$, dan misalkan $\mathrm{x}=\mathrm{s}$ adalah solusi $f(x)=0$, sehingga $f(s)=0$ dan $s=g(s)$, maka selisih antara $x_{r+1}$ dengan s adalah

$$
\begin{aligned}
x_{r+1}-s=g\left(x_{r}\right) & -s \\
& =\frac{g\left(x_{r}\right)-s}{\left(x_{r-s}\right)}\left(x_{r}-s\right)
\end{aligned}
$$


Dengan menerapkan teorema rata-rata, didapat kriteria konvergensi metode titik tetap, yaitu :

$$
x_{r+1}-s=g^{\prime}(t)\left(x_{r}-s\right)
$$

Dan galat iterasi ke-n adalah

$$
\varepsilon_{n+1}=g^{\prime}(t)-s_{r}
$$

\section{E. Pemrograman Matlab}

Matlab merupakan bahasa pemogramandengan kemampuan tinggi dalam bidang komputasi.Matlab mempunyai kemampuam mengintegrasikan komputasi, visualisai, dan pemrograman, maka Matlab sering digunakan dalam bidang riset-riset yang memerlukan komputasi numerikyang kompleks. Pemograman Matlab meliputi :

- Matematika dan komputasi

- Pembentukan Algoritma

- Akuisisi data

- Pemodelan, simulasi, danpembuatan prototype

- Analisis data, eksplorasi, dan visualisasi

- Grafik sains, dan rekayasa

Matlab merupakan kepanjangan dari Matrix Laboratory. Sesuai namanya struktur data yang terdapat dalam Matlab menggunakan matrik atau array berdimensi dua (double), maka penguasaan teori matrik sangat disarankan bagi pengguna Matlab agar mudah dalam mempelajari dan memahami operasi-operasi atlab.

Seperti dalam bahasa pemograman lain, Matlab juga memiliki variabel, namun dalam penulisannya tidak perlu dideklarasikan, karena Matlab mampu mendeteksi tipe data variabel dari isi variabel tersebut. Aturan penulisan variabel pada Matlab sama dengan aturan penulisan pada pemograman lainnya, yaitu bersifat case sensitive diawali dengan huruf dan selanjutnya boleh dengan boleh menggunakan gabungan huruf dan angka atau garis bawah. Matlab mampu mengenali 31 karakter pertama.

Sementara itu operator dalam Matlab dibagi menjadi 3 bagian yaitu, operator aritmatika, operator rasional, dan operator Logika.

Pemprograman dalam Matlab dikenal dengan nama M-File, yaitu sederetan perintah Matlab yang dituliskan secara berurutan sebagai sebuah file.Nama file yang tersimpan akan memiliki ekstensi .myang menandakan bahwa file yang dibuat adalah 
file Matlab. M-file dapat ditulis sebagai sebuah script atau dapat pula ditulis sebagai sebuah fungsiyang menerima argument atau masukan yang menghasilkan output.

\section{PEMBAHASAN}

Dalam penelitian ini akan dibandingkan kecepatan konvergensi menuju akar antara metode Bagi Dua (Bisection), Metode Tititk Tetap dengan Metode Newton Raphson dengan menggunakan aplikasi MATLAB yang dituliskan diatas.

Misalkan salah satu hasil proses adalah menghitung akar persamaan dari fungsi

$$
f(x)=e^{x}-5 x^{2}, \text { dengan galat } \varepsilon=0,00001
$$

Dengan metode bagi dua (bisection) :

\begin{tabular}{|c|c|c|c|c|c|c|c|c|}
\hline$r$ & a & C & b & $f(a)$ & f(b) & \multicolumn{2}{|c|}{ Lebarnya } & $E$ \\
\hline 0 & 0.000000 & 0.500000 & 1.000000 & 1.000000 & 0.398721 & -2.281718 & 0.500000 & 0.398721 \\
\hline 1 & 0.500000 & 0.750000 & 1.000000 & 0.398721 & -0.695500 & -2.281718 & 0.250000 & -0.27731 \\
\hline 2 & 0.500000 & 0.625000 & 0.750000 & 0.398721 & -0.084879 & -0.695500 & 0.125000 & -0.03384 \\
\hline 3 & 0.500000 & 0.562500 & 0.625000 & 0.398721 & 0.173023 & -0.084879 & 0.062500 & 0.068988 \\
\hline 4 & 0.562500 & 0.593750 & 0.625000 & 0.173023 & 0.048071 & 0.765157 & 0.031250 & 0.008317 \\
\hline 5 & 0.593750 & 0.609375 & 0.625000 & 0.048071 & -0.017408 & 0.765157 & 0.015625 & -0.00084 \\
\hline 6 & 0.593750 & 0.601563 & 0.609375 & 0.048071 & 0.015581 & -0.017408 & 0.007813 & 0.000749 \\
\hline 7 & 0.601563 & 0.605469 & 0.609375 & 0.015581 & -0.000851 & 0.861592 & 0.003906 & $-1.3 \mathrm{E}-05$ \\
\hline 8 & 0.601563 & 0.603516 & 0.605469 & 0.015581 & 0.007380 & -0.000851 & 0.001953 & 0.000115 \\
\hline 9 & 0.603516 & 0.604492 & 0.605469 & 0.007380 & 0.003268 & 0.885320 & 0.000977 & $2.41 \mathrm{E}-05$ \\
\hline 10 & 0.604492 & 0.604980 & 0.605469 & 0.003268 & 0.001210 & 0.885320 & 0.000488 & $3.95 \mathrm{E}-06$ \\
\hline 11 & 0.604980 & 0.605225 & 0.605469 & 0.001210 & 0.000179 & 0.885320 & 0.000244 & 2.17E-07 \\
\hline 12 & 0.605225 & 0.605347 & 0.605469 & 0.000179 & -0.000336 & 0.885320 & 0.000122 & $-6 E-08$ \\
\hline 13 & 0.605225 & 0.605286 & 0.605347 & 0.000179 & -0.000078 & -0.000336 & 0.000061 & $-1.4 \mathrm{E}-08$ \\
\hline 14 & 0.605225 & 0.605255 & 0.605286 & 0.000179 & 0.000051 & -0.00007 & 0.000031 & $9.08 \mathrm{E}-09$ \\
\hline 15 & 0.605255 & 0.605270 & 0.605286 & 0.000051 & -0.000014 & 0.886428 & 0.000015 & $-7 E-10$ \\
\hline 16 & 0.605255 & 0.60526 & 0.605270 & 0.000051 & 0.000018 & -0.000014 & 0.000008 & $9.33 \mathrm{E}-10$ \\
\hline
\end{tabular}


Dengan metode Titik Tetap didapat keluaran sebagai berikut :

$\begin{array}{ccc}i & x_{r} & x_{r+1}-x_{r} \\ 0 & 0.500000 & - \\ 1 & 0.574234 & 0.074234 \\ 2 & 0.595948 & 0.021714 \\ 3 & 0.602453 & 0.006506 \\ 4 & 0.604416 & 0.001963 \\ 5 & 0.605010 & 0.000593 \\ 6 & 0.605189 & 0.000180 \\ 7 & 0.605244 & 0.000054 \\ 8 & 0.605260 & 0.000016 \\ 9 & 0.605265 & 0.000005 \\ 10 & 0.605266 & 0.000002 \\ 11 & 0.605267 & 0.000000 \\ & & \\ \text { Hampiran akar } \mathrm{x}=0.605267\end{array}$

Dengan metode Newton Raphson didapat keluaran sebagai berikut :

$\begin{array}{ccl}i & x_{r} & X_{r+1}-x_{r} \\ 0 & 0.500000 & - \\ 1 & 0.618976 & 0.118976 \\ 2 & 0.605444 & 0.013532 \\ 3 & 0.605266 & 0.000177 \\ 4 & 0.605267 & 0.000000 \\ \text { Hampiran akar } x=0.605267\end{array}$

Dan dari beberpa contoh lain didapat hasil yang sama dimana kecepatan konvergensi metode Newton Raphson lebih cepat tercapai rata-rata lebih cepat $64 \%$ dibanding metode titik tetap.

\section{KESIMPULAN}

Metode Numerik adalah suatu teknik yang digunakan untuk memformulasikan persoalan matematika, sains dan rekayasa sedemikian sehingga dapat diselesaikan dengan cara operasi perhitungan aritmatika biasa, namun hasilnya berupa angka hampiran sehingga mengandung galat. Perhitungan pencarian akar persamaan non linier menggunakan metode Titik Tetap dan Metode Newton Raphson. Metode Titik Tetap dan metode Newton Raphson merupakan metode terbuka dengan langkah awal menentukan nilai awal dan toleransi galat dan iterasimaksimumnya. Dengan bantuan 
aplikasi Matlab kemudian membandingkan kecepatan konvergensinya melalui beberapa contoh fungsi pada galat 0,00001, dapat disimpulkan bahwa, Metode Newton Raphson secara umum lebih cepat convergen dibanding metode lainnya dengan rata-rata $64 \%$ lebih cepat.

\section{DAFTAR PUSTAKA}

Capra, Steven C and Canale 1991, "Numerical Method for Engineers with Personal Computer Aplications", MacGraw-Hill Book Company.

EEPI, ITS,. Modul Praktikum Data Sinyal Digital, Surabaya.

Koonin, Steven E ., Meredith, dawn C. 1990. Computational Physics, USA : AddisonWesley Publishing Company, Inc.

Press H., Flannery P., Teulosky A., Vetterling T. 1987. Numerical recipes, Cambridge : Press Syndicate of the Cambridge University.

Rahadian Hadi, 2001,"Pemrograman MatLab.”, Jakarta, PT. Elex Media Komputindo.

Rinaldi Munir, 2008, “Metode Numerik”, edisi revisi ke-2., Informatika, Bandung.

Sahid, 2011., "Pengantar Komputasi Numerik dengan MATLAB”., Andi Offset., Yogyakarta. 